\title{
Environmental Impact Matrix for Bucharest, Romania
}

\author{
MARIN RUSANESCU ${ }^{1}$, CARMEN OTILIA RUSANESCU2* \\ ${ }^{1}$ Valplast Industrie, 9 Preciziei Blvd., 062202, Bucharest, Romania \\ ZUniversity Politechnica, Faculty of Biotechnical Systems Engineering, Splaiul Independentei 313, 060042, Bucharest, \\ Romania
}

\begin{abstract}
The objective of this study was to provide an environmental impact assessment for the municipality of Bucharest. To touch this objective, air samples were taken from five monitoring stations and water from two rivers during 2007-2015. On the basis of all the information collected, the environmental impact assessment was carried out with the help of the Rapid Impact Assessment Matrix. Considering the surroundings of all monitoring stations, the air quality at which the inhabitants of Bucharest are exposed can be considered good. The Rapid Impact Assessment Matrix (RIAM) is a tool for analyzing, organizing and presenting the results of a holistic environmental impact assessment and ensuring a transparent and permanent record of the analysis process, organizing the environmental impact assessment procedure, which leads to a considerable reduction in the type of environmental impact assessment. The simple, structured form of the matrix allows for rapid and accurate in-depth reconstruction and analysis of selected components. This flexibility makes the method a powerful tool both for making and evaluating environmental impacts. The matrix has the ability to perform series of operations to compare variants; is able to compare assessments made in different sectors. The evaluation steps contained in the matrix allow for both quantitative and qualitative data to be evaluated.
\end{abstract}

Keywords: Rapid matrix evaluation, environmental impact, air pollution, water pollution

The Rapid Impact Assessment Matrix (RIAM) method was applied to highlight which of the environmental components would be most affected by pollutants.

The impact matrix method consists of building a matrix in which the evaluated activities are specified on a coordinate, and the other coordinates are the potentially affected environmental factors. At the intersection of activities with environmental factors, the intensity and importance of impact are quantified [19-22]. Using this method allows us to analyze all possible relationships, which makes the overall assessment more objective. The method allows the assessment of both direct and indirect impacts. Impact assessment matrices typically use ladder scales and scales to differentiate the roles of differenttypes of activities and environmental factors, which give a complex character to the method. Among the advantages of the method are: the ability to compare different types of impacts based on common judgments, transparency, flexibility, ease and economy [1].

This matrix was modeled on Pastakia and Jensen in 1998 [17]. This is a useful tool for organizing, analyzing and presenting the results of the environmental impact assessment.

Initially, RIAM was developed to compare alternatives within a project, butitcan also be used to compare different plans and programs in terms of their impact on the environment [1, 2].

The matrix can be modified according to the different criteria that the evaluator wishes to achieve, provided the Scale Assessment Scale offered by Pastakia is a variable one $[3,4]$.

Sources of environmental degradation are all anthropogenic activities that exceed the environmental support capacity and require significant changes in the functionality and structure of natural ecosystems and human communities [19, 23-28]. Air pollution in Bucharest has a specific character, primarily due to the location of residential areas close to industrial areas and traffic in Bucharest, (Ilfov County taking dispersion and emissions here), the existence of multiple sources, different heights of sources Pollution, as well as an uneven distribution of these sources [21]. Environmental pollution has been studied by $[6,13,20,25,27,28]$.

Sources of air pollution are industrial fixed sources, usually concentrated on existing industrial platforms, new industrial areas, generally located along the Capital Ring Road, the expansion on large areas of new residential areas, motor traffic, in particular along the national roads connecting Bucharest with the highway traffic on the highway [7].

Figure 1 shows the spatial distribution of sources of environmental degradation in Bucharest.

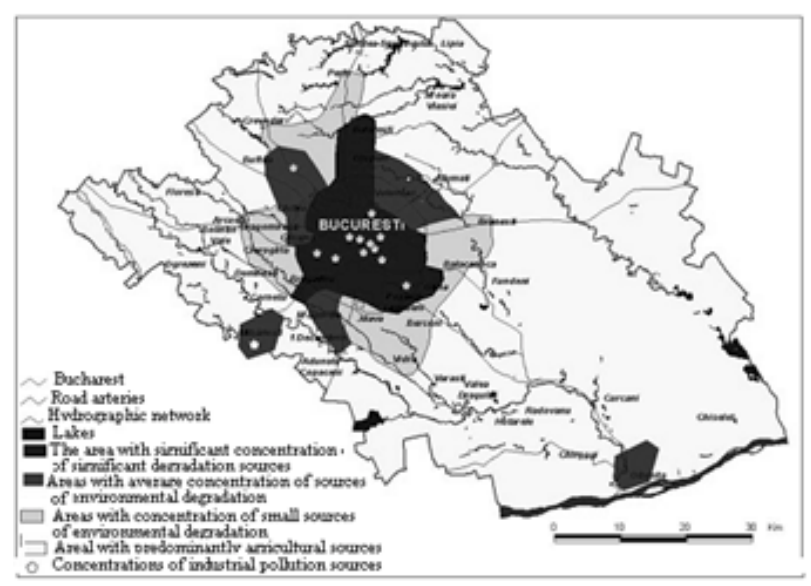

Fig.1 Spatial distribution of sources of environmental degradation in Bucharest [5] 


\section{Experimental part}

\section{Materials and methods}

The Rapid Impact Assessment Matrix is a tool for analyzing, organizing and presenting the results of the environmental impact assessment and ensuring a transparent and permanent record of the analysis process, while organizing the environmental impact assessment procedure. The simple, structured form of the matrix allows for rapid and accurate in-depth reconstruction and analysis of selected components [8-10].

The impact of the activities is evaluated to the environmental components and for each component a score is determined using the defined criteria, thus ensuring a measurement of the potential impact on the environmental components [11]. The method allows the assessment of both direct and indirect impacts [12, 14, 18].

Stages of application of the MERI method: accuracy of evaluation criteria and steps; defining the environmental aspects considered and grouping by class; calculation of environmental scores for each environmental aspect; conversion of individual environmental scores by impact categories; the precision of the impact category for each class of environmental aspects [14].

The method allows the assessment of both direct and indirect impact.

The calculation procedure for the Rapid Impact Assessment Matrix involves the following equations:

$$
\begin{aligned}
& \mathrm{A} 1 \times \mathrm{A} 2=\mathrm{At} \\
& \mathrm{B} 1+\mathrm{B} 2+\mathrm{B} 3=\mathrm{Bt} \\
& \mathrm{At} \times \mathrm{Bt}=\mathrm{ES}
\end{aligned}
$$

Where: $A 1, A 2, B 1, B 2, B 3$ - evaluation criteria by the RIAM method [17]

At, Bt - scores obtained by multiplying, respectively adding the values assigned to the evaluation criteria

ES - environmental score for the analyzed factor.

The standard evaluation criteria set out fall into two major types:

A - criteria that can individually change the achieved environmental score

$B$ - Individual criteria that can not change the environmental score.

The amount of grades in group (B) is then multiplied by the value resulting from the multiplication of grades in group (A), thus providing a final evaluation score (ES).

$E S$ is the environmental score for the analyzed factor [17-19].

The Rapid Impact Assessment Matrix (RIAM) requires the definition of specific assessment components through a categorization process, and these environmental components fall into one of the four categories defined below: physical / chemical; Relating to all physical and chemical aspects of the environment; biological / ecological On all the biological aspects of the environment; sociological / cultural; On all human aspects of the environment, including cultural issues; economic / operational; The qualitative identification of the temporary and permanent economic consequences of changing the environment $[1,11,17]$.

In order to ensure a safer assessment system, ES individual scores are listed grouped by category so that they can be compared. After obtaining environmental scores, they are converted into impact categories $(\mathrm{Cl})$ based on the conversion scale below.

The final evaluation for each component is made according to these categories. Once the ES scores have been fixed in a category, they can be presented individually or grouped by the component type and can be presented in graphical or numerical form, as required by the representation.

\section{Results and discussions}

In order to use the described evaluation system, a matrix comprising cells showing the criteria used in relation to each defined component is made for each project variant. In each cell, the notes to the individual criteria are entered. Using the above formulas, the Environmental Score (ES) is calculated and recorded.

Rapid Impact Assessment Matrix evaluation. Results, Quantification, Discussions Following Environmental Impact Assessment of Pollutants Issued in Bucharest Romania [8] (table 1).

For the criterion of the importance of the condition, we awarded the 1 st note, because the air pollution in Bucharest is important only for the local area.

If the $\mathrm{CO}, \mathrm{SO}_{2}, \mathrm{NO}_{2}$ and $\mathrm{Cr}^{6+}$ emissions do not exceed the alert thresholds $\left(^{2}\right)$ against the maximum permitted concentrations in the applicable legislation, the magnitude of the effect is given (0), with no change in the status quo . Considering what has been said above, we have awarded Note 1 for the following criteria taken into account in this method: permanence, reversibility and cumulativity, with no changes in the environment. Based on the calculations and scores granted, the environmental score (ES ) for air emissions is 4 , falling within the $(+A)$ slightly positive impact category [20].

From the analysis of the data presented in figure 2 it is observed that for the 2007-2015 period, for Bucharest traffic stations for the $\mathrm{SO}_{2}$ pollutant, there is a general tendency to reduce the annual average concentrations, which were generally below the limit values of $40 \mu \mathrm{g} / \mathrm{m}^{3}$.

For $\mathrm{SO}_{2}$ no special problems were reported, with registered ${ }^{2}$ concentrations falling below the limit values $\left(350 \mu \mathrm{g} / \mathrm{m}^{3}\right)$ or daily $\left(125 \mu \mathrm{g} / \mathrm{m}^{3}\right)$ in 2013.

Compared with previous years, sulfur dioxide

\begin{tabular}{|c|c|c|c|c|c|c|c|}
\hline \multicolumn{2}{|c|}{ Environmental Component / ES Criteria } & $\overline{\mathrm{A}_{1}}$ & $\overline{\mathrm{A}_{2}}$ & $\overline{\mathrm{B}_{1}}$ & $\overline{\mathrm{B}_{2}}$ & $\overline{\mathrm{B}_{3}}$ & $\overline{E S}$ \\
\hline \multirow{6}{*}{ Air emissions } & Total dusts & 1 & $\overline{0}$ & 1 & 1 & 1 & $\overline{0}$ \\
\hline & $\mathrm{CO}$ & 1 & 0 & 1 & 1 & 1 & 0 \\
\hline & $\mathrm{SO}_{2}$ & 1 & 0 & 1 & 1 & 1 & 0 \\
\hline & $\mathrm{NO}_{2}$ & 1 & 0 & 1 & 1 & 1 & 0 \\
\hline & $\mathrm{Cr}^{3+}$ & 1 & 0 & 1 & 1 & 1 & 0 \\
\hline & Heavy metals & 1 & 1 & 1 & 1 & 1 & $4(+A)$ \\
\hline
\end{tabular}
concentrations remain at the same level well below the limit values for human health protection. For sulfur dioxide,
Table 1

RAPID AIR IMPACT ASSESSMENT MATRIX 


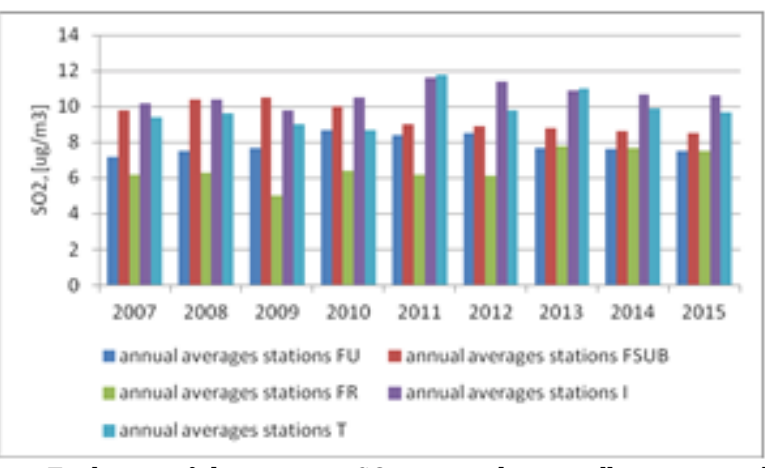

Fig. 2.Evolution of the average $\mathrm{SO}_{2}$ atmospheric pollutant annual concentrations recorded at traffic stations in Bucharest during 2007-2015. FU = urban fund, FSUB = suburban fund, FR = rural $/$ regional fund, $I=$ industrial, $T=$ transport

in 2013 there was no exceedance of the alert threshold at any monitoring station [20].

Annual average concentrations of nitrogen dioxide were analyzed. $\mathrm{NO}_{2}$ concentrations in the air are assessed using the hourly limit value for human health protection $(200 \mu \mathrm{g}$ $/ \mathrm{m}^{3}$ ) allowed to exceed 18 times per year and the annual limitvalue for human health protection $\left(40 \mu \mathrm{g} / \mathrm{m}^{3}\right)$. Annual average concentrations of nitrogen dioxide in air show exceedances in the annual limit value for human health $\left(40 \mu \mathrm{g} / \mathrm{m}^{3}\right)$ in Bucharest at the following stations that monitor traffic pollution: in 2009 Lacul Morii $\left(61 \mu \mathrm{g} / \mathrm{m}^{3}\right)$, $\operatorname{Titan}\left(68 \mu \mathrm{g} / \mathrm{m}^{3}\right)$, Mihai Bravu $\left(43.35 \mu \mathrm{g} / \mathrm{m}^{3}\right)$, Mihai Bravu $\left(50 \mu \mathrm{g} / \mathrm{m}^{3}\right)$ in 2010, Drumul Taberei $(41.96 \mu \mathrm{g} / 2012$ in Mihai Bravu $\left(60 \mu \mathrm{g} / \mathrm{m}^{3}\right)$ and Mihai Bravu $\left(45 \mu \mathrm{g} / \mathrm{m}^{3}\right)$ in Mihai Bravu $\left(60 \mu \mathrm{g} / \mathrm{m}^{3}\right)$ and Mihai Bravu $\left(45 \mu \mathrm{g} / \mathrm{m}^{3}\right)$, In 2015 also at Mihai Bravu (43 $\left.\mu \mathrm{g} / \mathrm{m}^{3}\right)$ (fig. 3) [20].

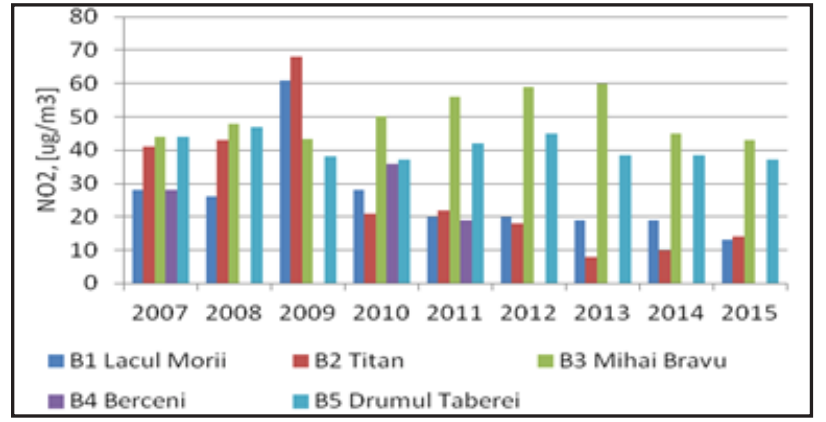

Fig. 3 The annual average $\mathrm{NO}_{2}$ concentrations recorded in Bucharest during the period 2007-2015
For the $\mathrm{NO}_{2}$ pollutant (the limit value for human health protection has exceeded more than 18 times in 2007 and 2008 , and the situation continues in the years to come).

Annual average values have fallen sharply since 2009 compared to previous years. However, annual average values exceed the annual limit value for human health protection at Mihai Bravu station due to road traffic.

\section{Suspensions}

The monitored pow ders, according to the requirements of the EU Directives, are PM10 and PM 2.5 powders, particles with aerodynamic diameter less than $10 \mu \mathrm{m}$ or less than $2.5 \mu \mathrm{m}$. These fine powders are the most dangerous, as they can enter very deep into the respiratory system and cause or accrue lung diseases.

No exceedance of the limit value for human health protection ( $10 \mathrm{mg} / \mathrm{mc}$, averaged over $8 \mathrm{~h}$ ) was observed for CO (carbon monoxide) concentration.

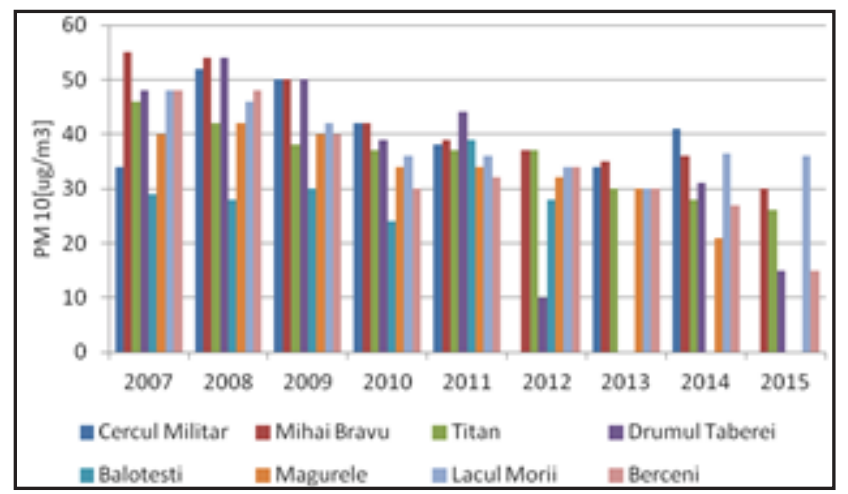

Fig. 4 Evolution of annual PM10 averages over 2007-2015

\section{Heavy metals}

The annual average concentrations of $\mathrm{Pb}$ were below the annual limit value for human health protection $(0.5 \mu \mathrm{g}$ $\left./ \mathrm{m}^{3}\right)$.

For cadmium, no annual target $\left(5 \mu \mathrm{g} / \mathrm{m}^{3}\right)$ was exceeded at any of the monitoring stations.

Because in the legislation in force the maximum admissible concentrations for $\mathrm{Cr}^{6+}$, sulphides and $\mathrm{H}_{2} \mathrm{~S}$ and extractable substances in groundwater are notmentioned, we did not give any note of the criteria discussed in this method.

\begin{tabular}{|c|c|c|c|c|c|c|c|c|}
\hline \multicolumn{2}{|c|}{ Environmental Component / ES Criteria } & $\overline{A_{1}}$ & $\overline{\mathrm{A}_{2}}$ & $\overline{\mathrm{B}_{1}}$ & $\overline{\mathrm{B}_{2}}$ & $\overline{\mathrm{B}_{3}}$ & $\overline{\mathrm{ES}_{\mathrm{i}}}$ & $\begin{array}{l}\text { Environmental } \\
\text { Score }\end{array}$ \\
\hline \multirow{10}{*}{ Drinking water } & $\overline{\mathrm{pH}}$ & 1 & $\overline{0}$ & 1 & $\overline{1}$ & 1 & $\overline{0}$ & \multirow[t]{10}{*}{$-24(-\mathrm{C})$} \\
\hline & $\mathrm{Pb}^{2-}$ & 1 & 0 & 1 & 1 & 1 & 0 & \\
\hline & CBO5 & 1 & -1 & 2 & 2 & 2 & -6 & \\
\hline & Mn & 1 & -1 & 2 & 2 & 2 & -6 & \\
\hline & MTS & 1 & -1 & 2 & 2 & 2 & -6 & \\
\hline & Coliforms fecal & 1 & -1 & 2 & 2 & 2 & -6 & \\
\hline & Sulfides and $\mathrm{H}_{2} \mathrm{~S}$ & - & - & - & - & - & - & \\
\hline & $\mathrm{Cr}^{5+}$ & - & - & - & - & - & - & \\
\hline & $\mathrm{Pb}^{2-}$ & 1 & 0 & 1 & 1 & 1 & 0 & \\
\hline & Chromium total & 1 & 0 & 1 & 1 & 1 & 0 & \\
\hline
\end{tabular}

Table 2

RAPID ASSESSMENT OF IMPACT ON DRINKING WATER 
Concentrations determined for Total $\mathrm{Cr}, \mathrm{Pb}^{2+}$, Suspensions do not exceed the alert threshold $(* * *)$ so we awarded Score 0 for Criterion A2 and Note 1 for Criteria B1, $\mathrm{B} 2$ and $\mathrm{B} 3$, with no changes to the status quo .

We have given note 2 on the degree of permanence, reversibility and cumulativity, the effects being temporary, reversible and non-cumulative.

According to the calculations and the scores granted, the environmental score for the environmental component - drinking water (EIS) is (-24), falling within the medium category $(-C)$ moderate negative impact, $[1,4,11]$.

\section{Conclusions}

They were taken air samples from five monitoring and water stations from two rivers over the period 2007-2015. On the basis of all the information collected, the environmental impact assessment was carried out with the help of the Rapid ImpactAssessment Matrix. In general, considering the surroundings of all monitoring stations, the air quality at which the inhabitants of Bucharest are exposed can be considered good. The RIAM method has been introduced into computer programs, which allows for rapid analysis. Due to its ability to use qualitative data, the method can be used at various levels within the development cycle, thus providing guidance on possible positive and negative effects in a more efficient way than with other methods. The image produced by RIAM (in matrix values and histograms obtained) represents the real representation of the judgments made by the evaluators. Another valuable feature of RIAM is that the steps used for each criterion are defined; consequently, subjective reasoning is understood by the learner. This accuracy is related to the transparency of RIAM records.

The RIAM method has been tested and validated for a real case study to assess the environmental impact (Bucharest, Romania). Two environmental components were analyzed: drinking water and air to prevent manmade disasters water and air pollution.

The proposed measures are aimed at reducing vehicle pollution, increasing green areas, controlling construction sites, etc. Bucharest is Romania's most powerful engine of development, providing a quarter of national GDP. Considering the increase in temperature, which has led to global warming, it is very useful to assess the environmental impact.

\section{References}

1. MUNTEAN, O.L., Environmental Impact Assessment, Ed. House of Sciences Book, Cluj-Napoca, 2005.

2. KUITUNEN, M. K., JALAVA, K. HIRVONEN, Environmental Impact Assessement Review, 28, 312-320, 2008.

3. IJAS, A., KUITUNEN, M.K., JALAVE, K., Environmental Impact Assessemnent Review, 30, 82 - 89, 2010.

4. IRIMIA, G. I., MUNTEAN, L., MALSCHI, D., ProEnvironment 4, 121$130,2011$.

5. IOJ A, I.; Methods and techniques for assessing the environmental quality of the area metropolitan Bucharest, 2009.
6. JINESCU, GHE., PANTURU, E., RADULESCU, R., JINESCU, C.V., MARES, M., Excellence research - a favorable premise for the development of Romanian research space, vol. I, p.L2.11 (1-10), 2006.

7.*** Report on the state of environmental factors in Bucharest municipality 2013.

8. GLADE, T., Advances in natural and technological hazards - research 17,UK, 2001.

9. NICOLAE A., NICOLAE M., PREDESCU CR., SOHACIU M., Environmental Engineering and Management Journal, 8, 3, 453-456, 2009.

10. SHAKIB-MANESH, T. E., HIRVONEN, K. O., JALAVA, K. J., ALANDER, T. KUITUNEN, M. T., Environmental impact assessment review, 49, 49-56, 2014.

11. SUTHAR, SURINDRA, SAJ WAN, ANUPMA, SUSTAINABLE CITIESAND SOCIETY, 13, 12-19, 2014.

12.NEGREI C., Tools and methods for environmental engineering, Economic Press, Bucharest, 1999.

13. JINESCU, GHE., PANTURU, E., RADULESCU, R., JINESCU, C.V., MARES, M., ISOPENCU, G., Conference Excellence Research - A Way to Innovation, v.l, p.57(1-6), 2008.

14. LI WEI, XIE YUANBO, HAO FANGHUA, Environmental impact assessment review, 46, 13-24, 2014.

15. RUSANESCU, C. O., RUSANESCU, M., Hidraulica, 4, p. 7-11, 2013.

16. STEFANESCU, L., Researches on the environmental impact on the closing of areas from the metallogenic field Rosia Montana, doctoral thesis abstract, Cluj-Napoca, 2010.

17. PASTAKIA, C.M.R., JENSEN, A., Impact Assessment Review, 18, 461-482, 1998.

18. *** http://www.anpm.ro/

19. CABRERA, JMG, MARTINEZ, MRF, MATEOS, EJ M, J ournal of environmental monitoring, 5, 4, 547-549, 2003.

20.RUSANESCU, C. O., JINESCU, C., RUSANESCU, M., BEGEA, M., GHERMEC, O., Rev. Chim. (Bucharest), 69, no. 1, 2018, p. 105-111

21.GHERMEC, O., GHERMEC, C., DUBOVAN, S., RUSANESCU, C. 0. , Environmental Engineering and Management Journal, 12, 10, 20192023, 2013.

22. RUSANESCU, C. O., Hidraulica, 3, 31-35, 2014

23. ULMANU, M., MATSI, THE., ANGER, I, GAMENT, E., OLANESCU, G, PREDESCU, CR., SOHACIU, M., Sci.Bull, Series B: Chemistry and Materials Science, 69, 2, 109-116, 2007.

24. RUSANESCU, C.O., PARASCHIV G., BIRIS, S. ST., VOICU, G., RUSANESCU, M., BEGEA, M., ISB-INMATEH Agricultural and mechanical engineering, Bucharest, pp.171-176, 2016.

25. PANTURU, E., RADULESCU, R., JINESCU, C.V.., ISOPENCU G., FILCENCO-OLTEANU A., JINESCU, GHE., Excellence research - a favorable premise for the development of Romanian research space 2007.

26. RUSANESCU, C. O., POPESCU, IL. N., RUSANESCU, M., DAVID, L. International J ournal of Energy and Environment, Issue 4, Volume 4, pp. 113-121, 2010.

27. J INESCU, V., MANEA, S.E., JINESCU, C., Rev. Chim.(Bucharest), 68, no. 4, 2017, p. 656-665

28. GROS, F., URSU, A.V., DJ ELVEH, G., JINESCU, C., NISTOR, IL. D., JINESCU, GHE., Rev. Chim. (Bucharest), 61, no. 6, 2010, p. 590-594,

Manuscript received: 22.06 .2018 